\title{
Toll-like receptor-4 gene variations in Egyptian children with familial Mediterranean fever
}

\author{
Yomna Farag ${ }^{1 *}$ D, Samia Salah', Hanan Tawfik', Mai Hamed² and Huda Marzouk ${ }^{1}$
}

\begin{abstract}
Background: Familial Mediterranean fever (FMF) is an autosomal recessive disorder affecting people in the region of the Mediterranean Sea. It is usually associated with mutation in Mediterranean fever (MEFV) gene that encodes the pyrin protein, which affects the innate inflammatory response. Toll-like receptors (TLR) are a family of pattern recognition receptors that recognize pathogenic microbes and activate antimicrobial defense mechanisms. Toll-like receptor 4 (TLR-4) is concerned with recognition of gram-negative organisms. There is growing clinical evidence suggesting a role for expression of TLRs in the immune pathogenesis of FMF. Thus, the aim of the current study was to evaluate the presence of TLR-4 (p.Asp299Gly) and TLR-4 (p.Thr399lle) gene variants in association with Egyptian children having FMF, furthermore, its effect on disease course and severity.

Results: Seventy Egyptian children diagnosed as having FMF, together with 50 age and gender-matched controls were enrolled in the study. The TLR-4 (p.Asp299Gly) and (Thr399lle) gene variants were determined by PCR-RFLP analysis for all studied patients and controls. TLR-4 p.Asp299Gly gene variant was detected in 1 (1.4\%) of the patients and p.Thr399lle gene variant was detected in 2 (2\%). None of the controls had any of the two tested gene variants. All found variations were heterozygous. We could not find a statistically significant association with disease severity in cases with or without TLR-4 gene variants $(P=0.568)$. Patients with M694V gene mutation showed a higher disease severity $(P=0.035)$.

Conclusion: TLR-4 (p.Asp299Gly) and (p.Thr399lle) gene variants were not found to have a link with the occurrence, the clinical picture of FMF, its severity, and response to colchicine treatment in Egyptian children. M694V gene mutation seems to be associated with higher disease severity. Further larger studies are needed to verify these results.
\end{abstract}

Keywords: Familial Mediterranean fever, Toll-like receptor 4, Gene variants

\section{Background}

Familial Mediterranean fever (FMF) is an autoinflammatory autosomal recessive disease associated with mutation in MEFV (Mediterranean fever) gene, which is located on the short arm of chromosome 16 . This gene encodes the expression of pyrin protein, which has a role in the innate immune response. It

\footnotetext{
* Correspondence: yomnafarag@yahoo.com

${ }^{1}$ Pediatrics Rheumatology Department, Faculty of Medicine, Cairo University, Cairo, Egypt

Full list of author information is available at the end of the article
}

suppresses the production of inflammatory cytokines specially interleukin (IL-1 ß) [1, 2].

Familial Mediterranean fever (MEFV) gene mutations interrupt the expression of pyrin, leading to intermittent episodes of uncontrolled inflammation [3].

Toll-like receptors (TLRs) constitute a family of transmembrane proteins expressed by various cell types, including immune cells. They identify pathogens and initiate inflammatory signaling pathways [4]. Discovery of TLRs increased our understanding of how the innate immune response senses various structures of 
microorganisms and trigger the signaling pathway, causing release of cytokines [1].

About 15 types of TLRs have been identified; among them is TLR-4. It mediates inflammatory signaling by recognizing the lipopolysaccharide (LPS) on gramnegative bacterial cell wall. TLR-4 (p.Asp299Gly) and TLR-4 (p.Thr399Ile) polymorphisms downregulate inflammation [5].

Innate immunity is a common factor between FMF and toll-like receptors [6]. Stimulation of the TLRs causes the activation of protein signal cascades, including Interleukin-1 receptor (IL-1 R) associated kinase pathway. This activates nuclear transcription factorkappa B. Furthermore, mutant pyrin proteins in FMF are unable to inhibit the production of IL-1ß, a cytokine involved in promoting apoptosis, thus allowing persistence of macrophages and inflammation [7, 8].

Genetic variations of TLRs have been found to increase the susceptibility to autoimmune and allergic diseases [9]. Furthermore, expression of FMF disease might be affected by some unknown modifying genes, besides the well-established $M E F V$ gene mutations [10].

Single nucleotide variations of the TLR-4 genes have been associated with receptor hypo-responsiveness and susceptibility to bacterial, fungal, and viral infections [1]. An important question had been raised; whether TLRs gene variations would affect the immune responses against infections, thus, affect the course of FMF [11].

There is some clinical evidence suggesting a role for expression of TLRs in FMF [12]. Furthermore, some studies worked on finding an association between the low prevalence of single nucleotide polymorphisms (SNPs) in TLRs-4 genes and FMF disease [11, 13, 14].

Kawamoto et al. suggested that FMF patients, whose attacks are triggered by the menstrual cycle, might have fewer TLR4 promotor genotypes that allow gramnegative bacteria to colonize the urinary tract without symptoms [1]. Thus, we hypothesized that TLR-4 (p.Asp299Gly) and TLR-4 (p.Thr399Ile) gene variations might affect FMF in Egyptian children.

The aim of this study was to evaluate the presence of TLR-4 (p.Asp299Gly) and (p.Thr399Ile) gene variants in association with Egyptian children having FMF, including its effect, if any, on disease course and severity.

\section{Methods}

This study was conducted on 120 children, including 70 diagnosed as having FMF. They were recruited from our Pediatric Rheumatology Clinic. The control group included 50 age and gender-matched children who came for follow-up at the outpatient surgery clinic of the same hospital for elective pre-operative assessment. The control group does not have any symptoms suggestive of autoimmune disease. The study was conducted during the period from January 2017 to December 2018. Laboratory investigations were done in Clinical and Chemical Pathology Department Laboratories, Kasr Al Ainy Hospital.

All patients were diagnosed according to FMF pediatric criteria [15]. Their age at time of study ranged from 2-16 years. Patients diagnosed as having an associated autoimmune disorder were excluded from the study.

Full history was taken from patients including history of parents' consanguinity, family history of FMF and other autoimmune diseases, age at disease onset, age at disease diagnosis, and duration of illness. Number of attacks per year, durations of attacks/hour, and clinical pattern of disease attacks (fever, abdominal pain, chest pain, arthritis, erysipelas-like rash, testicular affection, and history of vasculitis) were also included. History of colchicine dosing was taken in full details including duration of therapy/year, starting dose and current dose in $\mathrm{mg} /$ day, frequency of attacks/year, and duration of attacks/hour before and after colchicine therapy and compliance. Finally, response to colchicine therapy was assessed by FMF-50 score [16].

Disease severity was assessed by FMF severity score [17]. Familial Mediterranean fever (MEFV) gene variation status of the patients was recruited from their files. Complete blood picture (CBC), C-reactive protein (CRP), erythrocyte sedimentation rate (ESR), and urine analysis were done to all participants at the time of study.

The study was approved by the Local Ethical Committee of Faculty of Medicine, Cairo University. All participants in this study were informed and written consents were taken from their parents or legal guardian of the child.

\section{Specimen collection and storage}

Four milliliters of venous blood was withdrawn from all subjects and divided in to two parts: $2 \mathrm{ml}$ were collected in a sterile vacutainer containing ethylene diamine tetraacetate "EDTA" which were used for DNA extraction. Samples were kept frozen at $-20^{\circ} \mathrm{C}$ till time of DNA extraction and analysis. Two milliliters were collected on plain tubes, left for $10 \mathrm{~min}$ to clot, and then centrifuged at $3000 \mathrm{rpm}$ for $5 \mathrm{~min}$, the separated serum was used for routine laboratory investigations including CBC, CRP, ESR, serum creatinine, and urine analysis to check for proteinuria.

\section{Genomic DNA extraction}

Extraction of genomic DNA was done from peripheral blood using a (TIAN amp Genomic DNA Kit Intro Biotechnology) according to the manufacturer's instructions. 
Table 1 Identified bands of Asp299Gly and Thr399lle genotypes after trans-illumination by ultraviolet trans-illuminator

\begin{tabular}{lll}
\hline Genotype & Size of fragment & Number of bands detected \\
\hline Asp299Gly & & One band \\
Wild genotype & $249 \mathrm{bp}^{*}$ & Two bands \\
Homozygous mutant genotype & 223 and $26 \mathrm{bp}$ & Three bands \\
Heterozygous genotype & 249,223, and $26 \mathrm{bp}$ & One band \\
Thr399lle & & Two bands \\
Wild genotype & $406 \mathrm{bp}$ & Three bands \\
Homozygous mutant genotype & 377 and $29 \mathrm{bp}$ & 406,377, and $29 \mathrm{bp}$ \\
\hline
\end{tabular}

*bp base pair

Analysis of toll-like receptor 4 TLR-4 (p.Asp299Gly) and TLR-4 (p.Thr399Ile) gene variants was done using polymerase chain restriction-restriction fragment length polymorphism (PCR-RFLP) procedure.

Amplification of extracted genomic DNA (PCR) was done using the following primers: for TLR-4 (p.Asp299Gly), sense: 5'-GAT TAG CAT ACT TAG ACTACT ACC TCC ATG-3', and anti-sense: 5'-GAT CAA CTT CTG AAA AAG CAT TCC CAC-3'. As for TLR-4 (p.Thr399Ile), sense: 5'-GGT TGC TGT TCT CCA AAG TGA TTT TGG GAG AA-3', and antisense: 5' -ACC TGA AGA CTG GAG AGT GAG TTA AAT GCT-3'. The thermal cycler was programmed for initial denaturation at $95^{\circ} \mathrm{C}$ for $10 \mathrm{~min}, 35$ cycles of amplification consisting of denaturation at $94{ }^{\circ} \mathrm{C}$ for $30 \mathrm{~s}$, annealing for $30 \mathrm{~s}$ at $61^{\circ} \mathrm{C}$ for Asp299Gly (NOCI) enzyme, and $62^{\circ} \mathrm{C}$ for Thr399lle (HINF) enzyme and extension at $72{ }^{\circ} \mathrm{C}$ for $1 \mathrm{~min}$. The amplified samples were then run in parallel on $2 \%$ agarose gel using gel electrophoresis and visualized on Ultra Violet transilluminator to detect presence of amplified material.

Each PCR product was digested to completion with FastDigest (NOCI-HF) restriction endonuclease for TLR4 (p.Asp299Gly) and FastDigest (HinfI) restriction endonuclease for TLR-4 (p.Thr399Ile).
The digested products were separated by electrophoresis on agarose $3 \%$ gel and visualized using ethidium bromide (Table 1), (Figs. 1 and 2).

\section{Statistical methods}

Data were analyzed using SPSS $\odot$ Statistics version 24 (SPSS $\odot$ Corp., Armonk, NY, USA). Normally distributed numerical data were presented as mean \pm SD and intergroup differences were compared using the unpaired $t$ test. Skewed numerical data were presented as median and interquartile range and between-group differences were compared using the Mann-Whitney test. Categorical variables were presented as number and percentage. Fisher's exact test was used to compare nominal data and the chi-squared test for trend to compare ordinal data. Association between FMF genes and disease severity were tested using rank biserial correlation (rrb). $P$ values $\leq 0.05$ were considered statistically significant.

\section{Results}

Demographic, clinical, and laboratory characteristics of the studied groups are represented in Table 2. Mean of age at disease onset was $4.9 \pm 2.9(0.5-12)$ years, while the time between first presentation and disease diagnosis showed a mean of $2.0 \pm 2.5 \quad(0.0-12.0)$ years.

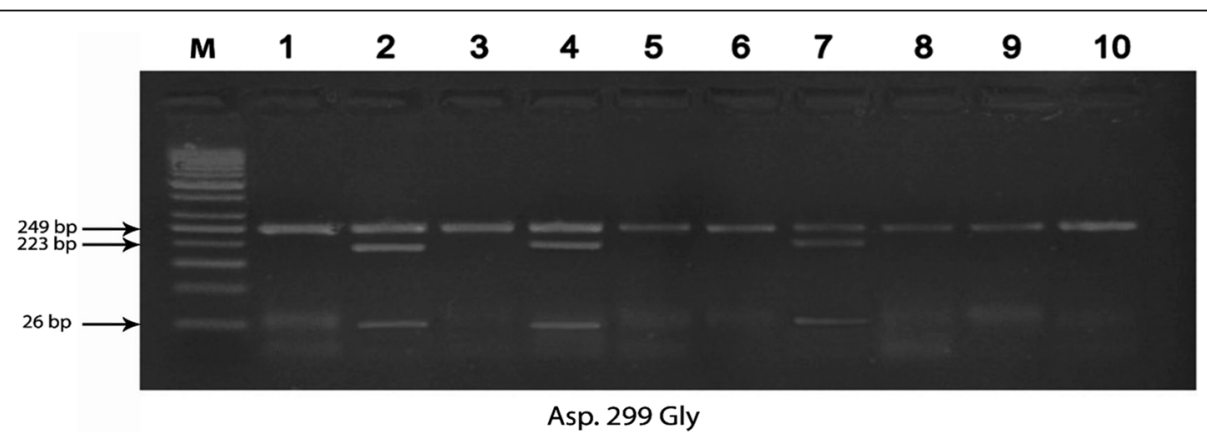

Fig. 1 Using RFLP restriction enzyme (NCOI-HF), the identified bands after transillumination by UV transilluminator. From left to right: Shows, M (DNA marker), DNA ladder (lane 1-10) in (50 bp ladder). Lanes $(2,4,7)$ show heterozygous genotype (Asp/Gly). Lanes (1, 3, 5, 6, 8, 9, and 10) show a wild genotype (Asp/Asp) 


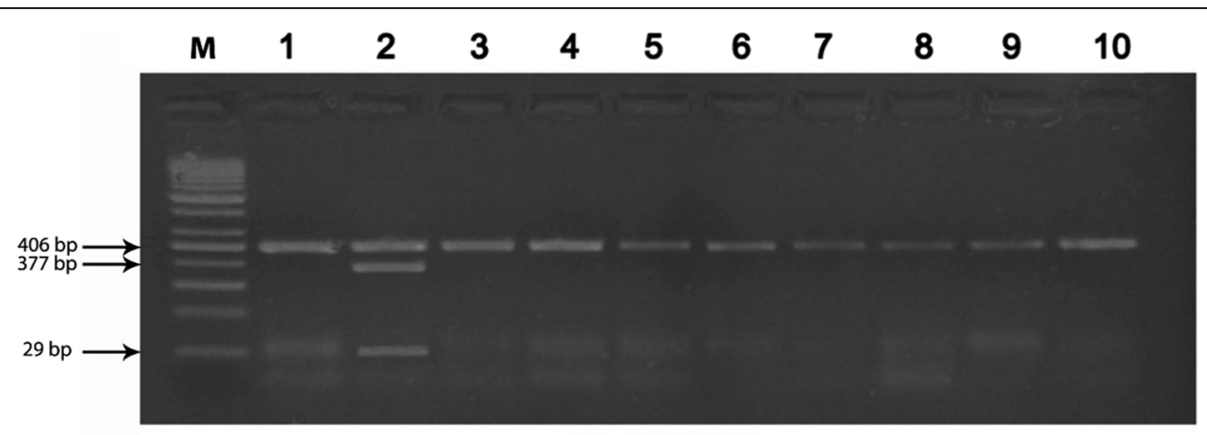

Thr. 399 lle

Fig. 2 Using RFLP restriction enzyme (Hinfl), the identified bands after transillumination by UV transilluminator. From left to right: M (DNA marker), DNA ladder (lane 1-10), and 50 bp ladder. Lanes (1, 3, 4, 5, 6, 7, 8, 9, and 10) show wild genotype (Thr/Thr). Lane (2) shows a heterozygous genotype (Thr/lle)

Table 2 Demographic, clinical, and laboratory characteristics of the studied groups regarding age, gender, clinical manifestations, disease severity, and presence of TLR4 gene mutations

\begin{tabular}{llll}
\hline Variables & Cases $(\boldsymbol{n}=\mathbf{7 0})$ & Controls $(\boldsymbol{n}=\mathbf{5 0})$ & $\boldsymbol{P}$ value \\
\hline Age (years), mean \pm SD & $9.5 \pm 3.5$ & $9.4 \pm 2.6$ & 0.840 \\
Gender & & & \\
$\quad$ Male $\boldsymbol{n}(\%)$ & $30(42.9 \%)$ & $28(56.0 \%)$ & 0.195 \\
$\quad$ Female $\boldsymbol{n}(\%)$ & $40(57.1 \%)$ & $22(44.0 \%)$ &
\end{tabular}

Clinical manifestations of FMF $n(\%)$

$\begin{array}{ll}\text { Abdominal pain } & 62(88.6 \%) \\ \text { Recurrent fever } & 55(78.6 \%) \\ \text { Arthritis } & 55(78.6 \%) \\ \text { Chest pain } & 30(42.9 \%) \\ \text { Myalgia } & 29(41.4 \%) \\ \text { Skin rash } & 4(5.7 \%)\end{array}$

Degree of disease severity $n(\%)$

$\begin{array}{ll}\text { Mild } & 14(20 \%) \\ \text { Moderate } & 20(28.6 \%) \\ \text { Severe } & 26(51.4 \%) \\ \text { Laboratory findings } & \\ \text { Positive CRP } & 6(8.6 \%) \\ \text { Proteinuria } & 1(1.4 \%) \\ \text { Anemia } & 1(1.4 \%) \\ \text { Leukocytosis } & 4(5.7 \%)\end{array}$

TLR-4 Asp299Gly genetic variation

\begin{tabular}{llll} 
Normal & $69(98.6 \%)$ & $48(96.0 \%)$ & 0.570 \\
Heterozygous & $1(1.4 \%)$ & $2(4.0 \%)$ & \\
TLR-4 Thr399lle genetic variation & & \\
Normal & $69(98.6 \%)$ & $50(100.0 \%)$ & 1.000 \\
Heterozygous & $1(1.4 \%)$ & $0(0.0 \%)$ & \\
\hline
\end{tabular}

Furthermore, disease duration had a mean of $4.4 \pm 2.7$ (1.0-12.0) years. Hemoglobin level had a mean value of $12.2 \pm 1.0(9.0-14.0) \mathrm{g} / \mathrm{dl}$. Total leucocyte count had a mean of $7 \pm 2(4-14) \times 1000 / \mathrm{mm} 3$. One patient $(1.4 \%)$ had normocytic normochromic anemia and 4 patients (5.7\%) had leukocytosis.

The mean duration of colchicine therapy was $2.7 \pm 1.9$ $(0.5-9.0)$ years. The starting dose in cases showed a mean of $0.89 \pm 0.44(0.25-2.0) \mathrm{mg} /$ day, while the current dose of colchicine at time of study had a mean of $1.13 \pm$ $0.48(0.25-2.0) \mathrm{mg} /$ day. Median and IQ range seen in Table 3.

Our result showed that the frequency of attacks decreases after colchicine therapy from a mean of $6 \pm 4$ (1$36)$ attacks/year to a mean of $2 \pm 2(0.0-12)$ attacks/year. Similarly, duration of the attacks decreased from a mean of $35 \pm 20$ (6-72) hours to a mean of $10 \pm 11(0-48)$ hours. Response to colchicine per FMF50 scores [16] showed non-responsiveness in 10 patients $(14.3 \%)$ compared to $60(85.7 \%)$ being responsive. Three patients (4.3\%) were non-compliant to therapy.

We found that $20(28.6 \%)$ patients carried a heterozygous MEFV gene mutation, 35 (50.0\%) were homozygous, and 15 (21.4\%) had compound heterozygous mutation. The most prevalent $F M F$ gene among patients was the E148Q, in $22(25.2 \%)$ patients, M694I in 20 (22.9\%), V726A in 18 (20.6\%), M680I in 16 (18.3\%), and M694V was present in 11 (12.6\%) patients.

The MEFV gene M694V had a weak association with disease severity with a rank biserial correlation coefficient $(\mathrm{rrb})$ of $0.253(P$ value $=0.035)$. Otherwise, there was no statistically significant association between any of the other FMF genes and severity of disease (all $P$ values $>0.05)$. Similarly, there was no statistically significant association between disease severity and presence of FMF gene mutation $(\mathrm{rrb}=0.069, P$ value $=0.572)$, as seen in Table 4. 
Table 3 Duration, starting dose, and current dose of colchicine therapy among cases

\begin{tabular}{|c|c|c|c|c|c|c|c|}
\hline \multirow[t]{2}{*}{ Variable } & \multirow[t]{2}{*}{ Min } & \multirow[t]{2}{*}{ Max } & \multirow[t]{2}{*}{ Median } & \multirow[t]{2}{*}{ IQ range } & \multicolumn{3}{|c|}{ Percentiles } \\
\hline & & & & & $25^{\text {th }}$ & $50^{\text {th }}$ & $75^{\text {th }}$ \\
\hline Duration of colchicine therapy (years) & 0.5 & 9.0 & 2.5 & $(1.0-3.5)$ & 1.0 & 2.5 & 3.5 \\
\hline Starting dose of colchicine (mg/day) & 0.25 & 2.00 & 1.00 & $(0.50-1.00)$ & 0.50 & 1.00 & 1.00 \\
\hline Current dose of colchicine (mg/day) & 0.25 & 2.00 & 1.00 & $(1.00-1.50)$ & 1.00 & 1.00 & 1.50 \\
\hline
\end{tabular}

The TLR-4 (p.Asp299Gly) gene variants were found normal in $69(98.6 \%)$ patients compared to $48(96.0 \%)$ of the controls. One $(1.4 \%)$ of the cases had heterozygous variation compared to $2(4.0 \%)$ of the controls, with $P=$ 0.570. TLR-4 (p.Thr399Ile) genetic variation was normal in $69(98.6 \%)$ cases compared to $50(100.0 \%)$ of the controls, while $1(1.4 \%)$ of the cases carried a heterozygous variation compared to none of the controls $(P=1.000)$.

Odds ratio of exposure among cases versus among control showed a result of 0.71 with no statistical significance $(P=0.732)$.

We did not find a significant correlation between frequency and duration of attacks and colchicine dosage among cases with and without TLR gene variations (Table 5).

As for disease severity in cases with TLR4gene variations, one $(7.1 \%)$ patient showed mild form of the disease severity, and another patient (2.8\%) showed severe form ( $P$ value 0.568$)$. Regarding response to treatment, the two (3.3\%) patients with TLR4gene variations showed good response to colchicine treatment.

\section{Discussion}

To the best of our knowledge, this is the first study about TLR-4 gene variants in Egyptian children with FMF. We could not find a significant correlation between TLR-4 (p.Asp299Gly) and (p.Thr399Ile) gene variants and clinical measures of FMF disease, its severity, and response to colchicine treatment. Furthermore, M694V gene mutation statistically correlated with higher disease severity $(P$ value $=0.035)$.

The low prevalence of TLR-4 gene variations that were found in this study was also reported in Egyptian patients with other autoimmune diseases. The Egyptian study by Taha et al. [4] did not find any of the TLR-4 (p.Asp299Gly) or TLR-4 (p.Thr399Ile) gene variations in patients with rheumatoid arthritis or systemic lupus erythematous or in the control group. They stated that the TLR-4 gene variations display ethnic differences. Africans have the highest frequency (16\%) [18], followed by Europeans (4-10\%) [19], whereas Asians do not display this type of gene variations [20]. It seems that Egyptians have a low prevalence for these types of gene variations.

This study comes in agreement with the results reported by the study done in Greece [11] who found no association between TLR-4 gene variations and the frequency of attacks or disease severity. Speletas et al. [11] found the allele frequency of TLR-4 (p.Asp299Gly) to be lower in FMF patients compared with controls, while two other Turkish studies $[13,21]$ found a lower prevalence among healthy controls. The latter two studies

Table 4 Association between FMF genes present in study subjects and FMF disease severity

\begin{tabular}{|c|c|c|c|c|c|c|c|c|c|}
\hline \multirow[b]{3}{*}{ Variable } & & \multicolumn{6}{|c|}{ Severity of FMF } & & \\
\hline & & \multicolumn{2}{|c|}{ Mild } & \multicolumn{2}{|c|}{ Moderate } & \multicolumn{2}{|c|}{ Severe } & \multicolumn{2}{|c|}{ Rank biserial correlation } \\
\hline & & $N$ & Row $\%$ & $N$ & Row \% & $N$ & Row \% & Coefficient $\left(r_{r b}\right)$ & $P$ value \\
\hline \multirow[t]{2}{*}{ FMF gene V627A } & Absent & 10 & $19.2 \%$ & 14 & $26.9 \%$ & 28 & $53.8 \%$ & -0.069 & 0.570 \\
\hline & Present & 4 & $22.2 \%$ & 6 & $33.3 \%$ & 8 & $44.4 \%$ & & \\
\hline \multirow[t]{2}{*}{ FMF gene E148Q } & Absent & 11 & $22.9 \%$ & 12 & $25.0 \%$ & 25 & $52.1 \%$ & 0.043 & 0.726 \\
\hline & Present & 3 & $13.6 \%$ & 8 & $36.4 \%$ & 11 & $50.0 \%$ & & \\
\hline \multirow[t]{2}{*}{ FMF gene M680I } & Absent & 9 & $17.0 \%$ & 16 & $30.2 \%$ & 28 & $52.8 \%$ & -0.099 & 0.413 \\
\hline & Present & 5 & $29.4 \%$ & 4 & $23.5 \%$ & 8 & $47.1 \%$ & & \\
\hline \multirow[t]{2}{*}{ FMF gene M694V } & Absent & 13 & $21.7 \%$ & 20 & $33.3 \%$ & 27 & $45.0 \%$ & $0.253^{*}$ & 0.035 \\
\hline & Present & 1 & $10.0 \%$ & 0 & $0.0 \%$ & 9 & $90.0 \%$ & & \\
\hline \multirow[t]{2}{*}{ FMF gene M694I } & Absent & 11 & $22.0 \%$ & 13 & $26.0 \%$ & 26 & $52.0 \%$ & 0.029 & 0.813 \\
\hline & Present & 3 & $15.0 \%$ & 7 & $35.0 \%$ & 10 & $50.0 \%$ & & \\
\hline \multirow[t]{2}{*}{ FMF gene mutation } & Absent & 1 & $50.0 \%$ & 0 & $0.0 \%$ & 1 & $50.0 \%$ & 0.069 & 0.572 \\
\hline & Present & 13 & $19.1 \%$ & 20 & $29.4 \%$ & 35 & $51.5 \%$ & & \\
\hline
\end{tabular}

Data are counts $(N)$ and row percentage (\%).

*There is a weak association between FMF gene M694V and severity of FMF $\left(r_{r b}, 0-253 ; P\right.$ value, 0.035$)$ 
Table 5 Relation between TLR-4 gene variations and age at disease onset, frequency, and duration of attacks before and after colchicine therapy and colchicine dosage

\begin{tabular}{llll}
\hline Variable & Negative $T L R-4$ gene variation $(\boldsymbol{n}=\mathbf{6 8})$ & Positive $\boldsymbol{T L R} \mathbf{- 4}$ gene variation $(\boldsymbol{n}=\mathbf{2})$ & $\boldsymbol{P}$ value \\
\hline Age at onset (years) & $4.75(0.5-12)$ & $5(5-5)$ & $6(4-8)$ \\
Frequency of attacks per year before colchicine & $4(1-36)$ & $1(1-1)$ & 0.750 \\
Frequency of attacks per year after colchicine & $1(0-12)$ & $42(36-48)$ & 0.545 \\
Duration of attacks before colchicine (h) & $24(6-72)$ & $15(6-24)$ & 0.794 \\
Duration of attacks after colchicine (h) & $6(0-48)$ & $1.25(1-1.5)$ & 0.459 \\
Starting dose of colchicine (mg/day) & $1(0.25-2)$ & $1.75(1.5-2)$ & 0.388 \\
Dose of colchicine at time of study (mg/day) & $1(0.25-2)$ & & 0.152 \\
\hline
\end{tabular}

found a higher prevalence of TLR-4 (p.Thr399Ile) gene variations among control. All genetic variations found were heterozygous, a finding similar to our study.

Soylu et al. agreed with our finding that the frequency of these gene variations did not differ between FMF patients and control [13].

Another study looking for the same TLR4 gene variants in Henoch-Schonlein purpura (HSP) observed a similar finding. They found a low prevalence of these variants in HSP with no effect on disease occurrence and presentation [22].

On the other hand, a meta-analysis study found a weak association between inflammatory bowel disease and the studied gene variants in Caucasians, but not Asians [23], highlighting the fact that the prevalence and effect of TLR gene variants are different among ethnicities.

Our study found an association between FMF disease severity and M694V gene mutation. This agreed with several Egyptian studies [23-25]. An Egyptian study by Alhaggar et al. suggested a link between this gene mutation and amyloidosis [26]. Researchers studying other ethnicities found a similar link [27-30].

In our study, the mean age of disease onset was $4.9 \pm$ 2.9 years. This was similar to Talaat et al. [31]. However, Salah et al. [32] and El-Garf et al. [33] found slightly older age of onset. Mean age of onset was also higher in a Syrian study [34] and a Turkish study [35]. Meanwhile, the age of onset in three other Turkish studies was almost similar [36-38]. These differences may be related to different ethnicities and different genetic backgrounds.

The most common disease manifestation in this study was abdominal pain, followed by fever. Abdominal pain came to be the first symptomatic presentation in several studies [32, 34, 36, 39]. However, other studies [33, 4042] reported more occurrence of fever than abdominal pain. This difference may be due to different sample sizes and different presentations in various regions.

Limitations of our study are the relatively small number of patients and control.

\section{Conclusion}

TLR-4 (p.Asp299Gly) and (p.Thr399Ile) gene variants were not found to have a link with the occurrence, the clinical picture of FMF, its severity, and response to colchicine treatment in Egyptian children. M694V gene mutation seems to be associated with higher disease severity. Further larger studies are needed to verify these results.

\begin{abstract}
Abbreviations
FMF: Familial Mediterranean fever; MEFV: Mediterranean fever gene; CBC: Complete blood count; CRP: C-reactive protein; ESR: Erythrocyte sedimentation rate; PCR-RFLP: Polymerase chain restriction-restriction fragment length polymorphism; IL-1: Interleukin-1; HSP: Henoch-Schonlein purpura; IBD: Inflammatory bowel disease
\end{abstract}

\section{Acknowledgements}

We are very grateful to the nurses and the secretary in our clinic, who work hard to organize and facilitate our work.

\section{Authors' contributions}

All authors have contributed significantly and all authors are in agreement with the content of the manuscript. YM: contributed in searching the literature, writing and editing the manuscript, and being the corresponding author. SS: contributed with the idea of the research, following the results, and writing the manuscript. HT: contributed in searching literature, collecting the data, and performing the statistical part of the research. $\mathrm{MH}$ : contributed in the laboratory part of the research and writing the methodology of the manuscript. HM: contributed in following the results and writing the manuscript. All authors read and approved the final manuscript.

\section{Funding}

No funding was obtained for this study.

\section{Availability of data and materials}

The datasets used and/or analyzed during the current study are available from the corresponding author on reasonable request.

\section{Ethics approval and consent to participate}

This study was approved by the ethical scientific committee of the Faculty of Medicine, Cairo University. Informed written consents were taken from the parents or the patient's guardians according to guidelines of the ethical committee of the Faculty of Medicine, Cairo University.

\section{Consent for publication}

Written informed consents to publish the data contained within this study were taken from the parents or the patient's legal guardians.

Competing interests

The authors declare that they have no competing interests. 


\section{Author details}

'Pediatrics Rheumatology Department, Faculty of Medicine, Cairo University, Cairo, Egypt. ${ }^{2}$ Clinical and Chemical Pathology Department, Faculty of Medicine, Cairo University, Cairo, Egypt.

\section{Received: 16 July 2020 Accepted: 9 December 2020}

\section{Published online: 01 February 2021}

\section{References}

1. Kawamoto S, Masutani R, Kurata K, Shima E, Iwatani Y, Takubo T (2019) Tolllike receptor 4 promoter polymorphisms in a familial Mediterranean fever patient with asymptomatic bacteriuria. Clinical case reports 7:155

2. Salehzadeh F, Enteshary A, Moshkbar M (2019) Colchicine plus dapsone in colchicine-resistant FMF patients. Case reports in rheumatology 2019

3. Tatar E, Karatas M, Aykas A, Okut G, Bozkaya G, Uslu A (2017) Infections after renal transplant in recipients with familial Mediterranean fever: a lifethreatening issue. Exp Clin 15:240-243

4. Taha HA, Sheir RE, Shafy SSA, Mohamed LM (2014) Genotypic analysis of Asp299Gly and Thr399lle polymorphisms of TLR4 in Egyptian patients with rheumatoid arthritis and systemic lupus. Egypt J Internal Med 26:15

5. Anwar MA, Choi S (2017) Structure-activity relationship in TLR4 mutations: atomistic molecular dynamics simulations and residue interaction network analysis. Sci Rep 7:43807

6. Schmitt C, Humeny A, Becker C-M, Brune K, Pahl A (2002) Polymorphisms of TLR4: rapid genotyping and reduced response to lipopolysaccharide of TLR4 mutant alleles. Clin Chem 48:1661-1667

7. Masumoto J, Dowds TA, Schaner P, Chen FF, Ogura Y, Li M, Zhu L, Katsuyama T, Sagara J, Taniguchi SI (2003) ASC is an activating adaptor for NF-KB and caspase-8-dependent apoptosis. Biochem Biophys Res Commun 303:69-73

8. Semlali A, Jalouli M, Parine NR, Al Amri A, Arafah M, Al Naeem A, Ajaj SA Rouabhia M, Alanazi MS (2017) Toll-like receptor 4 as a predictor of clinical outcomes of estrogen receptor-negative breast cancer in Saudi women. OncoTargets and therapy 10:1207

9. Arbour NC, Lorenz E, Schutte BC, Zabner J, Kline JN, Jones M, Frees K, Watt $J$, Schwartz DA (2000) TLR4 mutations are associated with endotoxin hyporesponsiveness in humans. Nat Genet 25:187

10. Ben-Zvi I, Brandt B, Berkun Y, Lidar M, Livneh A (2012) The relative contribution of environmental and genetic factors to phenotypic variation in familial Mediterranean fever (FMF). Gene 491:260-263

11. Speletas M, Kalala F, Mitroulis I, Papadopoulos V, Merentiti V, Germenis AE, Ritis K (2009) TLR2 and TLR4 polymorphisms in familial Mediterranean fever. Hum Immunol 70:750-753

12. Ozen S, Berdeli A, Türel B, Kutlay S, Yalcinkaya F, Arici M, Besbas N, Bakkaloglu A, Yilmaz E (2006) Arg753Gln TLR-2 polymorphism in familial mediterranean fever: linking the environment to the phenotype in a monogenic inflammatory disease. J Rheumatol 33:2498-2500

13. Soylu A, Ateş H, Cingöz S, Türkmen M, Demir BK, Tunca M, Sakızlı M, Cirit M, Ersoy R, Ülgenalp A (2011) TLR polymorphisms in FMF: association of TLR-2 (Arg753Gln) and TLR-4 (Asp299Gly, Thre399lle) polymorphisms and myeloid cell TLR-2 and TLR-4 expression with the development of secondary amyloidosis in FMF. Inflammation 34:379-387

14. Karakose MZ, Yapali S, Salman E, Aksu K, Karakose S, Akarca US (2015) TLR2 and TLR4 gene expression levels and associated factors during acute attack and attack-free periods in familial Mediterranean fever. Clin Rheumatol 34: 785-790

15. Yalçınkaya F, Özen S, Özçakar ZB, Aktay N, Çakar N, Düzova A, Kasapçopur Ö, Elhan AH, Doğanay B, Ekim M (2009) A new set of criteria for the diagnosis of familial Mediterranean fever in childhood. Rheumatology 48: 395-398

16. Ozen S, Demirkaya E, Duzova A, Erdogan O, Erken E, Gul A, Kasapcopur O, Kasifoglu T, Kisacik B, Ozdogan H (2014) FMF50: a score for assessing outcome in familial Mediterranean fever. Ann Rheum Dis 73:897-901

17. Mor A, Shinar Y, Zaks N, Langevitz P, Chetrit A, Shtrasburg S, Rabinovitz E, Livneh A: Evaluation of disease severity in familial Mediterranean fever. In Seminars in arthritis and rheumatism. Elsevier; 2005: 57-64.

18. Mockenhaupt FP, Cramer JP, Hamann L, Stegemann MS, Eckert J, Oh N-R, Otchwemah RN, Dietz E, Ehrhardt S, Schröder NW (2006) Toll-like receptor (TLR) polymorphisms in African children: common TLR-4 variants predispose to severe malaria. Proc Natl Acad Sci 103:177-182
19. Adam R, Sturrock R, Gracie J (2006) TLR4 mutations (Asp299Gly and Thr399lle) are not associated with ankylosing spondylitis. Ann Rheum Dis 65:1099-1101

20. Zheng B, Li Q, Wei C, Qin J, Shou T, Zhou R, Shao J, Yang Y, Xiao C (2010) Lack of association of TLR4 gene Asp299Gly and Thr399lle polymorphisms with rheumatoid arthritis in Chinese Han population of Yunnan Province. Rheumatol Int 30:1249-1252

21. Emingil G, Berdeli A, Baylas H, Saygan BH, Gürkan A, Köse T, Atilla G (2007) Toll-like receptor 2 and 4 gene polymorphisms in generalized aggressive periodontitis. J Periodontol 78:1968-1977

22. Soylu A, Kizildag S, Kavukcu S, Cindoz S, Turkmen M, Demir BK, Sakizh M (2010) TLR-2 Arg753GIn, TLR-4 Asp299Gly, and TLR-4 Thr399lle polymorphisms in Henoch Schonlein purpura with and without renal involvement. Rheumatol Int 30:667-670

23. Wilson M, Abou-Elalla AA, Zakaria MT, Marzouk H, Fayed HL, Hanna MOF (2016) Serum amyloid A type 1 gene polymorphism in Egyptian children with familial Mediterranean fever. Pathobiology 83(6):295-300

24. El Gezery DA, Abou-Zeid AA, Hashad DI, El-Sayegh HK MEFV gene mutations in Egyptian patients with familial Mediterranean fever. Genet Test Mol Biomarkers 14(2):263-268

25. Talaat HS, Sheba MF, Mohammed RH, Gomaa MA, El Rifaei N, Farouk M, Ibrahim MF (2020) Genotype mutations in egyptian children with familial Mediterranean fever: clinical profile, and response to colchicine. Mediterr J Rheumatol 31(2):206-213

26. Al-Haggar MS, Yahia S, Abdel-Hady D, Al-Saied A, Al-Kenawy R, Abo-ElKasem R (2014) Phenotype-genotype updates from familial Mediterranean fever database registry of Mansoura University children' hospital, Mansoura. Egypt. Indian J Hum Genet 20(1):43-50

27. Cazeneuve C, Sarkisian T, Pêcheux C, Dervichian M, Nédelec B, Reinert P, Ayvazyan A, Kouyoumdjian JC, Ajrapetyan H, Delpech M, Goossens M, Dodé C, Grateau G, Amselem S (1999) MEFV-Gene analysis in Armenian patients with familial Mediterranean fever: diagnostic value and unfavorable renal prognosis of the M694V homozygous genotype-genetic and therapeutic implications. Am J Hum Genet 65(1):88-97

28. Ong FS, Vakil H, Xue $Y$, Kuo JZ, Shah KH, Lee RB, Bernstein KE, Rimoin DL, Getzug T, Das K, Deignan JL, Rotter Jl, Grody WW (2013) The M694V mutation in Armenian-Americans: a 10-year retrospective study of MEFV mutation testing for familial Mediterranean fever at UCLA. Clin Genet 84(1): $55-59$

29. Grossman C, Kassel Y, Livneh A, Ben-Zvi I (2019) Familial Mediterranean fever (FMF) phenotype in patients homozygous to the MEFV M694V mutation. Eur J Med Genet 62(6):103532

30. Aydın F, Çakar N, Özçakar ZB, Uncu N, Başaran O, Özdel S, Çelikel E, Elhan AH, Yalçınkaya F (2019) Clinical features and disease severity of Turkish FMF children carrying E148Q mutation. J Clin Lab Anal 33(4):e22852

31. Talaat HSE-D, Mohamed MF, El Rifai NMM, Gomaa MA (2012) The expanded clinical profile and the efficacy of colchicine therapy in Egyptian children suffering from familial Mediterranean fever: a descriptive study. Ital J Pediatr 38:66

32. Salah S, Rizk S, Lotfy HM, Houchi SE, Marzouk H, Farag Y (2014) MEFV gene mutations in Egyptian children with Henoch-Schonlein purpura. Pediatr Rheumatol 12:41

33. El-Garf A, Salah S, Iskander I, Salah H, Amin SN (2010) MEFV mutations in Egyptian patients suffering from familial Mediterranean fever: analysis of 12 gene mutations. Rheumatol Int 30:1293-1298

34. Jarjour RA, Al-Berrawi S (2015) Familial Mediterranean fever in Syrian children: phenotype-genotype correlation. Rheumatol Int 35:629-634

35. Duşunsel R, Dursun I, Gündüz Z, Poyrazoğlu MH, Gürgöze MK, Dundar M (2008) Genotype-phenotype correlation in children with familial Mediterranean fever in a Turkish population. Pediatr Int 50:208-212

36. Ece A, Çakmak E, Uluca Ü, Kelekçi S, Yolbaş İ, Güneş A, Yel S, Tan I, Şen V (2014) The MEFV mutations and their clinical correlations in children with familial Mediterranean fever in Southeast Turkey. Rheumatol Int 34:207-212

37. Inal A, Yilmaz M, Kendirli SG, Altintas DU, Karakoc GB (2009) The clinical and genetical features of 124 children with familial Mediterranean fever: experience of a single tertiary center. Rheumatol Int 29:1279-1285

38. Kizildag S, Dedemoglu F, Anik A, Catli G, Abaci A, Makay B, Bober E, Unsal E (2016) Association between vitamin D receptor polymorphism and familial Mediterranean fever disease in Turkish children. Biochem Genet 54:169-176

39. Yilmaz R, Ozer S, Ozyurt H, Erkorkmaz U Sahin S (2009) Familial Mediterranean fever gene mutations in the inner northern region of Turkey 
and genotype-phenotype correlation in children. J Paediatr Child Health 45: 641-645

40. Kilic A, Varkal MA, Durmus MS, Yildiz I, Ylldırm ZNY, Turunc G, Oguz F, Sidal M, Omeroglu RE, Emre S (2015) Relationship between clinical findings and genetic mutations in patients with familial Mediterranean fever. Pediatr Rheumatol 13:59

41. Padeh S, Livneh A, Pras E, Shinar Y, Lidar M, Feld O, Berkun Y (2010) Familial Mediterranean fever in children presenting with attacks of fever alone. J Rheumatol 37:865-869

42. Topaloglu R, Batu ED, Yıldız C, Korkmaz E, Özen S, Beşbaş N, Özalıın F (2018) Familial Mediterranean fever patients homozygous for E148Q variant may have milder disease. Int J Rheum Dis 21(10):1857-1862

\section{Publisher's Note}

Springer Nature remains neutral with regard to jurisdictional claims in published maps and institutional affiliations.

\section{Submit your manuscript to a SpringerOpen ${ }^{\circ}$ journal and benefit from:}

- Convenient online submission

- Rigorous peer review

- Open access: articles freely available online

High visibility within the field

- Retaining the copyright to your article

Submit your next manuscript at $\boldsymbol{\nabla}$ springeropen.com 